\title{
Academic Learning about Public Space. Knowledge Sharing toward Implementation of the New Urban Agenda
}

\author{
Luisa Bravo \\ City Space Architecture, Italy \\ luisa.bravo@cityspacearchitecture.org
}

In September 2018 City Space Architecture organized a conference in Venice titled 'Knowledge sharing toward implementation of the New Urban Agenda', included in the 'Past Present and Future of Public Space' international conference series started in 2014 with an inaugural three day event in Bologna'.

The first 'Past Present and Future of Public Space' conference in Bologna (2014) The 2014 Bologna conference hosted 4 keynote speakers from USA, Spain, Hong Kong and Japan, 5 lecturers, 4 invited speakers, 8 special sessions with 44 speakers, I workshop, and 16 parallel sessions for the discussion of 4 main themes and 16 topics:

- Morphology and Design with four topics: Historic Patterns: Conservation and Sustainability / Suburban World / Walkability, Cyclability, Green Corridors / Quality of Architecture and Urban Design

- Multidisciplinary Fields with four topics: Public Life from a Phenomenological Approach / Perception and Senses in the urban Space, City and Food / Urban Agriculture

- New Approaches with four topics: Publics and their Spaces / Lighter, Cheaper, Quicker Interventions / City as a Common Good / Mapping the Commons

- Emerging Trends with four topics: Urban Hacking / New Languages in the Public Realm / Smart Cities / Urban Happiness and Well-being.

The conference also included a cinema event, a guided tour in Bologna, a visit to the Museum of the History of Bologna where City Space Architecture opened the exhibition 'Pop Up City. Searching for Instant Urbanity', two art installations and a gala dinner. As collateral events, City Space Architecture organized a visit to the 14th International Architecture Exhibition in Venice Fundamentals, curated by Rem Koolhaas ${ }^{3}$,

\footnotetext{
' Read more about the first 'Past Present and Future of Public Space' international conference on Art, Architecture and Urban Design, that took place in Bologna in 2014:

http://www.cityspacearchitecture.org/?p=past-present-future-of-public-space

${ }^{2}$ Bravo, L. (20I6). "Pop-up City. Searching for instant urbanity”, The Journal of Public Space, I(I), I55158. https://www.journalpublicspace.org/index.php/jps/article/view/235

3 | 4th International Architecture Exhibition FUNDAMENTALS, curated by Rem Koolhaas McNamara https://www.labiennale.org/en/architecture/2014
} 
and the international symposium 'INTERSECTIONS. Expertise, Academic Research and Design from Barcelona, Beirut, Hong Kong, Brisbane, Auckland, Florence', that took place at the University of Florence ${ }^{4}$.

The Bologna conference was an overwhelming success, attended by more than 120 scholars, academic professors and professionals, together with artists, activists, photographers and film-makers ${ }^{5}$ from all over the world. After that, City Space Architecture worked to strengthen academic and professional collaborations worldwide that led to the foundation of the Past Present and Future of Public Space Research Group, and many of the papers presented and discussed at the conference have been published on The Journal of Public Space.

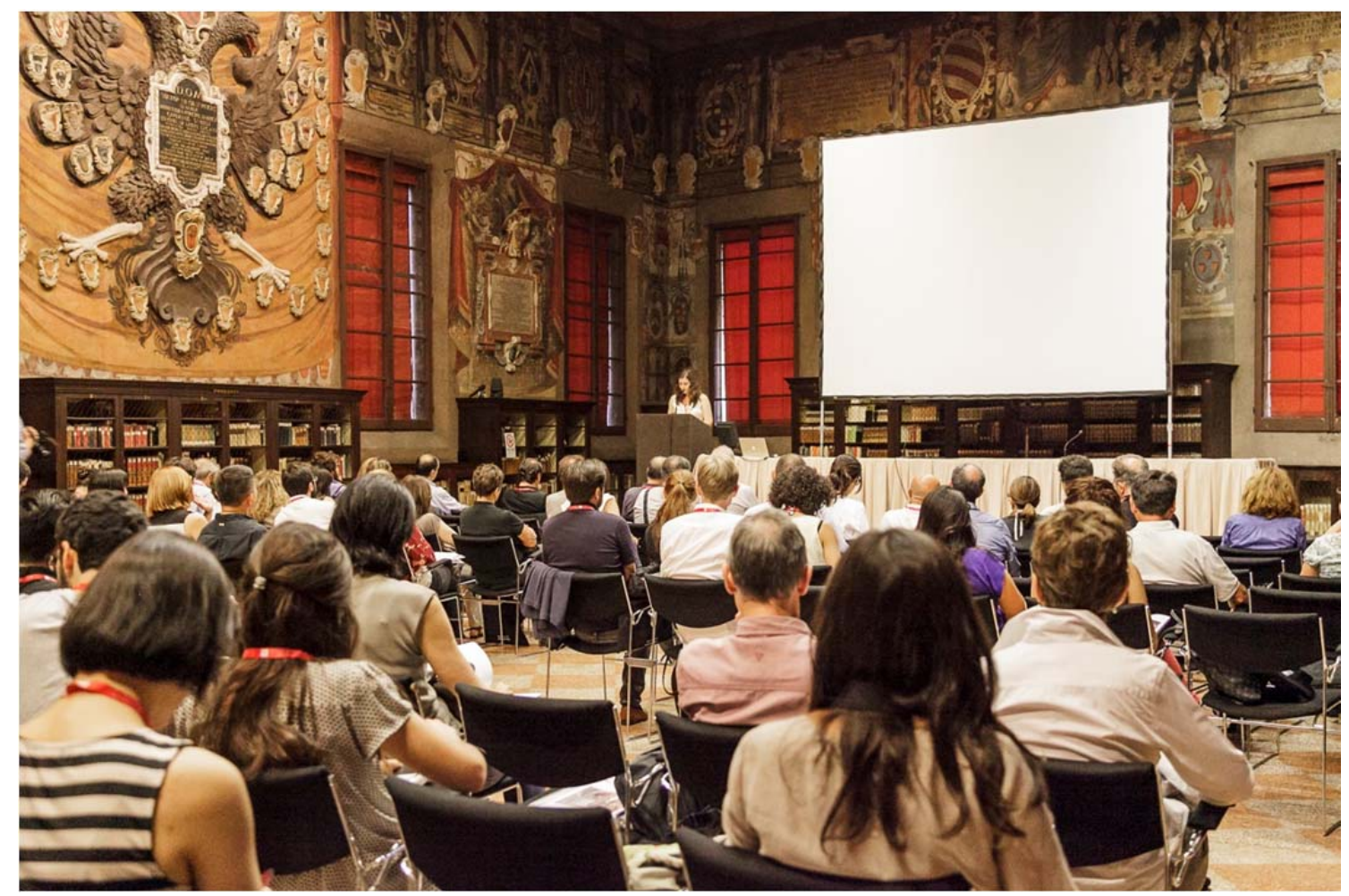

Figure I. Opening Ceremony of the first 'Past Present and Future of Public Space' international Conference on Art, Architecture and Urban Design in Bologna (2014). Picture by Elettra Bastoni.

The third 'Past Present and Future of Public Space' conference in Venice (20 I8) The 2018 conference was the third event of the successful series 'Past Present and Future of Public Space' and took place in Venice: City Space Architecture signed a cooperation agreement with La Biennale di Venezia within the 16th International Architecture Exhibition (Venice Architecture Biennale) - titled FREESPACE, curated by Yvonne Farrell and Shelley McNamara ${ }^{6}$ - in order to be included in the 'Biennale

\footnotetext{
${ }^{4}$ Read the full program of the Bologna conference: http://www.cityspacearchitecture.org/images/20I406/PPF_publicspace_program.pdf

${ }^{5}$ Read a short report of the Bologna conference (2014):

https://issuu.com/cityspacearchitecture/docs/ppfpublicspace_bologna vol I

${ }^{6}$ 16th International Architecture Exhibition FREESPACE, curated by Yvonne Farrell and Shelley McNamara: https://www.labiennale.org/en/architecture/2018.
} 
Sessions', a special program for Universities and Higher Education Institutions. This collaboration was intended as a continuation of the successful 'Biennale Session' that City Space Architecture promoted in 2016 at the Venice Architecture Biennale, which was the second event of the series 'Past Present and Future of Public Space', where we announced our participation to the Habitat III conference in Quito and officially launched The Journal of Public Space.

The 2018 conference in Venice was organized in partnership with UN-Habitat, ISOCARP - the International Society of City and Regional Planners, University of Auckland (New Zealand), and Hunan University (China).

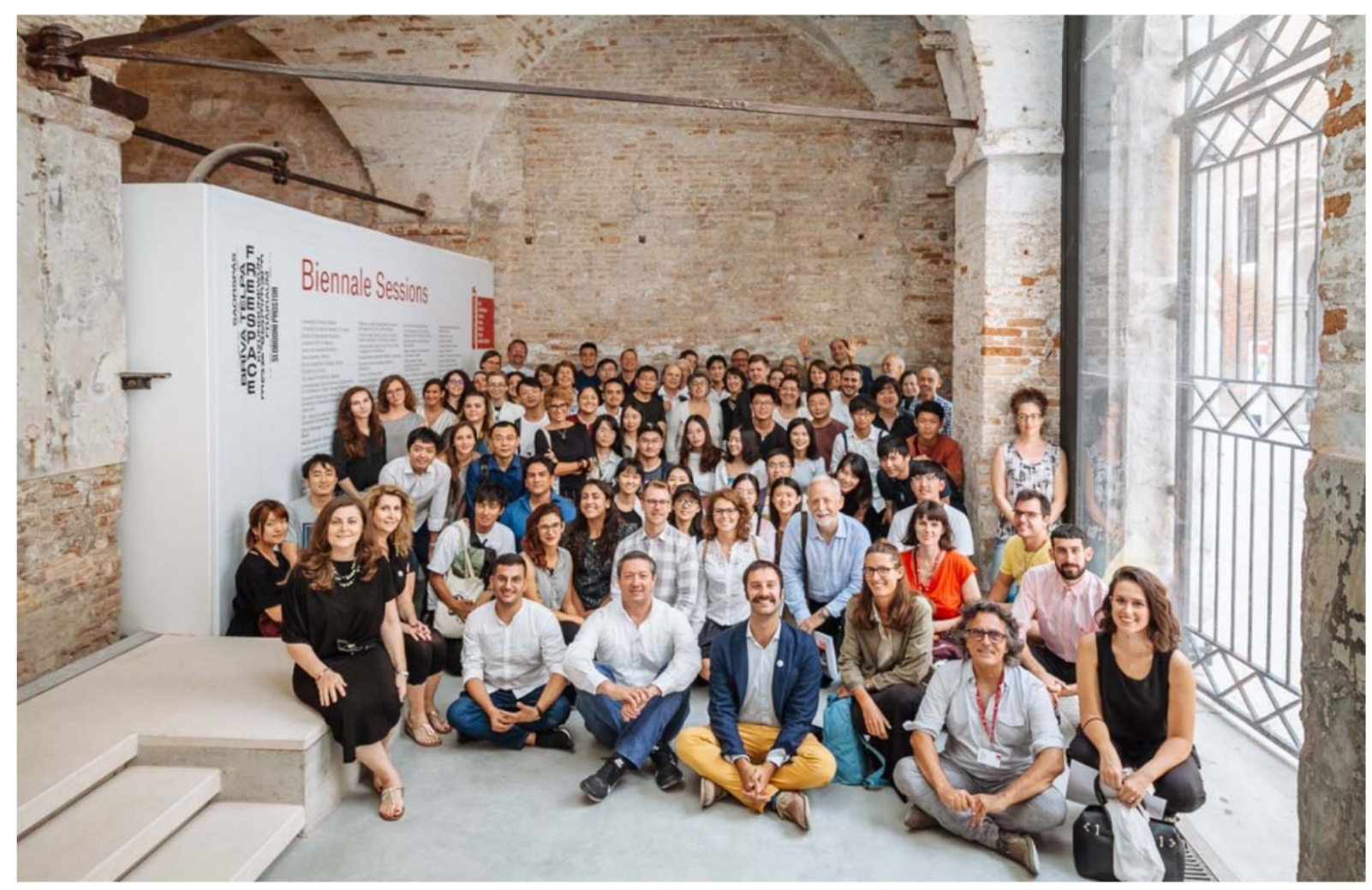

Figure 2. Participants of the third conference 'Past Present and Future of Public Space. Knowledge sharing toward implementation of the New Urban Agenda' in Venice (2018). Picture by Elettra Bastoni.

It was willing to strengthen City Space Architecture's efforts around the implementation of the New Urban Agenda adopted at the Habitat III conference and to continue the discussion on the importance of public space in cities, with the participation of students and young researchers. It was a three-day event including:

- a one-day international symposium

- a one-day international workshop for students

- a visit to the 16th International Architecture Exhibition

- three collateral events: the visit at the Cyprus pavilion 'I'm where you are' with the curator Yiorgos Hadjichristou, the visit at the Irish pavilion 'Free Market' with the curator Tara Kennedy and the visit at the Dutch pavilion 'Work, Body, Leisure' with Marieke Berkers, on the occasion of the launch of the book 'Dream your own future'. 
The symposium welcomed professors, researchers and students from: The Chinese University of Hong Kong, Hong Kong / The Graduate Centre, City University of New York, USA / Hunan University, China / IUAV University, Italy / Keio University, Japan / KTH Royal Institute of Technology, Sweden / KTH Centre for the Future of Places, Sweden / Lodz University of Technology, Poland / Manchester School of Architecture, United Kingdom / Meiji University, Japan / Politecnico di Milano, Italy / Pratt Institute, USA / Shanghai University, China / Stanford University, USA / Syracuse University in Florence, Italy / Tsinghua University, China / TU Vienna, Austria / Universidad Espíritu Santo, Ecuador / Universitat Politècnica de Catalunya, Spain / University of Auckland, New Zealand / University of Bologna, Italy / University of Cambridge, United Kingdom / University College Cork, Ireland / University of Florence, Italy / University of Nicosia, Cyprus / University of Palermo, Italy.

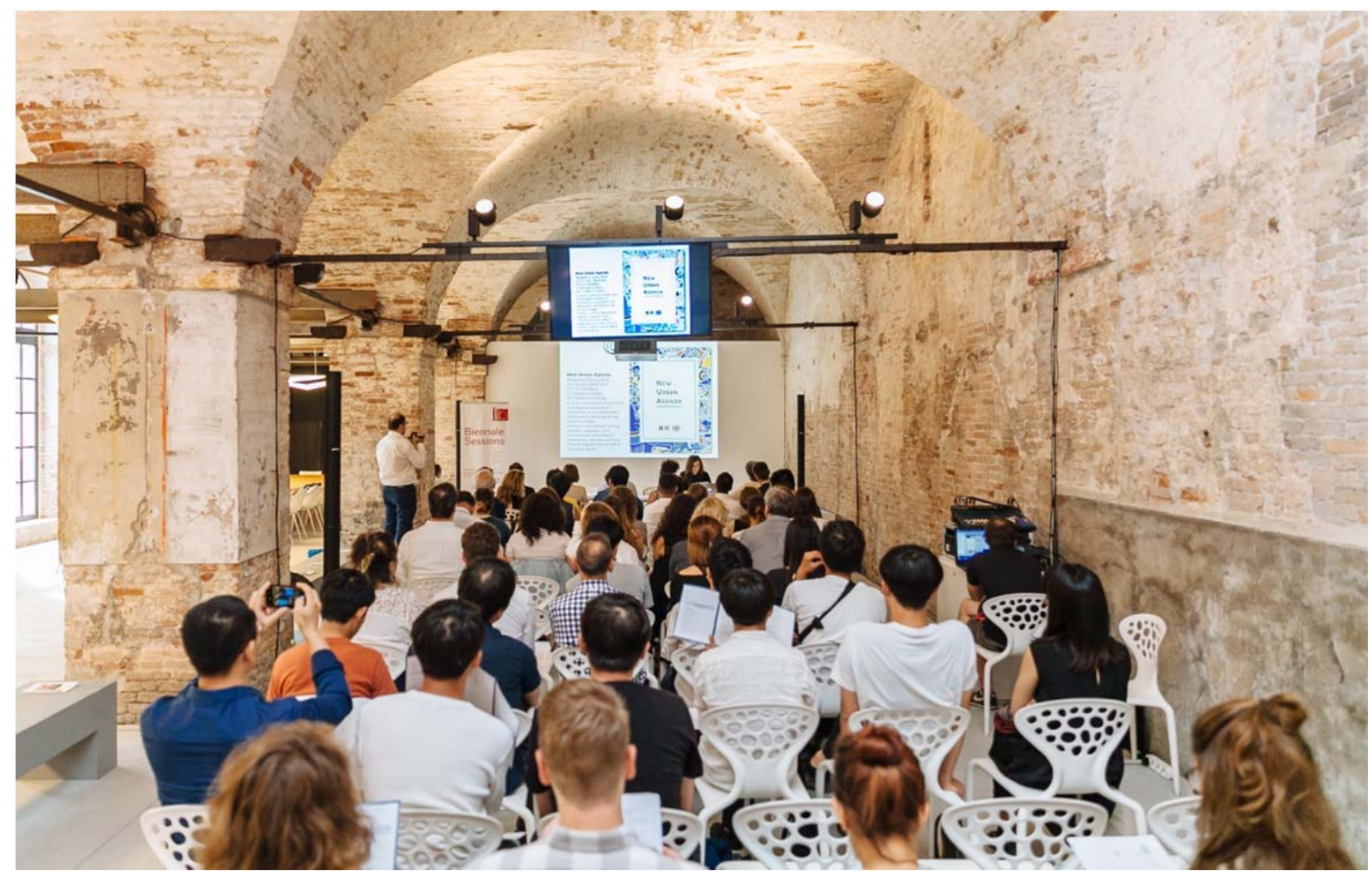

Figure 3. Participants of the third conference 'Past Present and Future of Public Space. Knowledge sharing toward implementation of the New Urban Agenda' in Venice (2018). Picture by Elettra Bastoni.

The symposium in Venice included ${ }^{7}$ :

- a session for the presentation of academic programs, projects and initiatives on public space, from USA, Austria, Hong Kong, Japan, Sweden, New Zealand and China;

- $\quad$ a session with ten lecturers, from Japan, Cyprus, Ireland, Italy, Spain, Ecuador, China and Sweden;

\footnotetext{
${ }^{7}$ Read the full program of the event: http://www.cityspacearchitecture.org/images/20I809/csa_venicebiennale2018.pdf.
} 
- a session with four roundtable discussions;

- a session entirely dedicated to students' research and activities on public space. Using the format of speed presentations, participants had an in-depth overview of students' research about public space from a various of topics and contexts, from Italy, USA, Spain, Ecuador, Sweden, Japan, Poland.
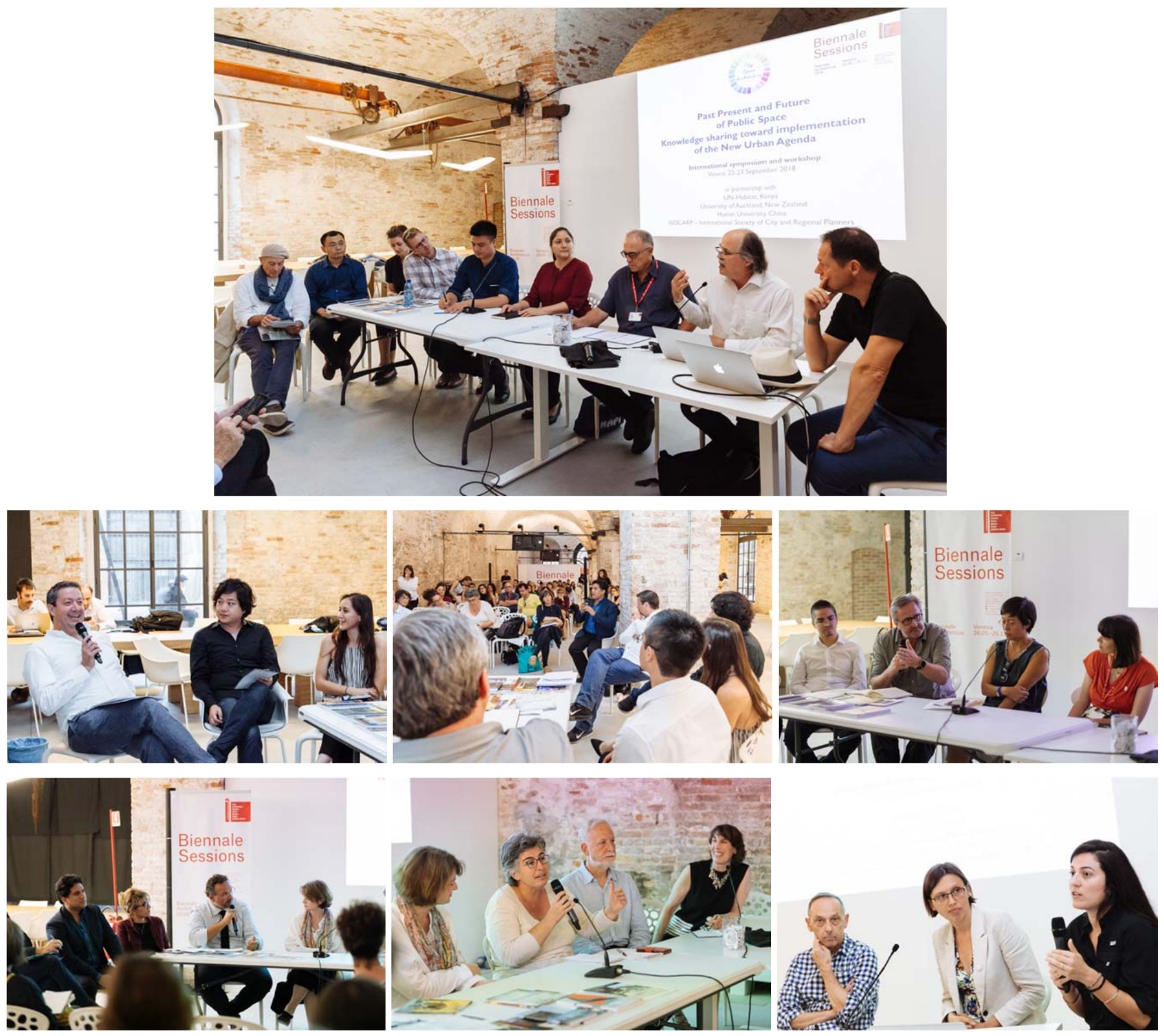

Figure 4/I0. Round table discussions at the third conference 'Past Present and Future of Public Space. Knowledge sharing toward implementation of the New Urban Agenda' in Venice (2018). Pictures by Elettra Bastoni.

The international workshop was promoted by City Space Architecture in collaboration with University of Auckland, Hunan University and Shanghai University and engaged 
students in lectures, presentations and a roundtable discussion. It was coordinated by Manfredo Manfredini, from University of Auckland.

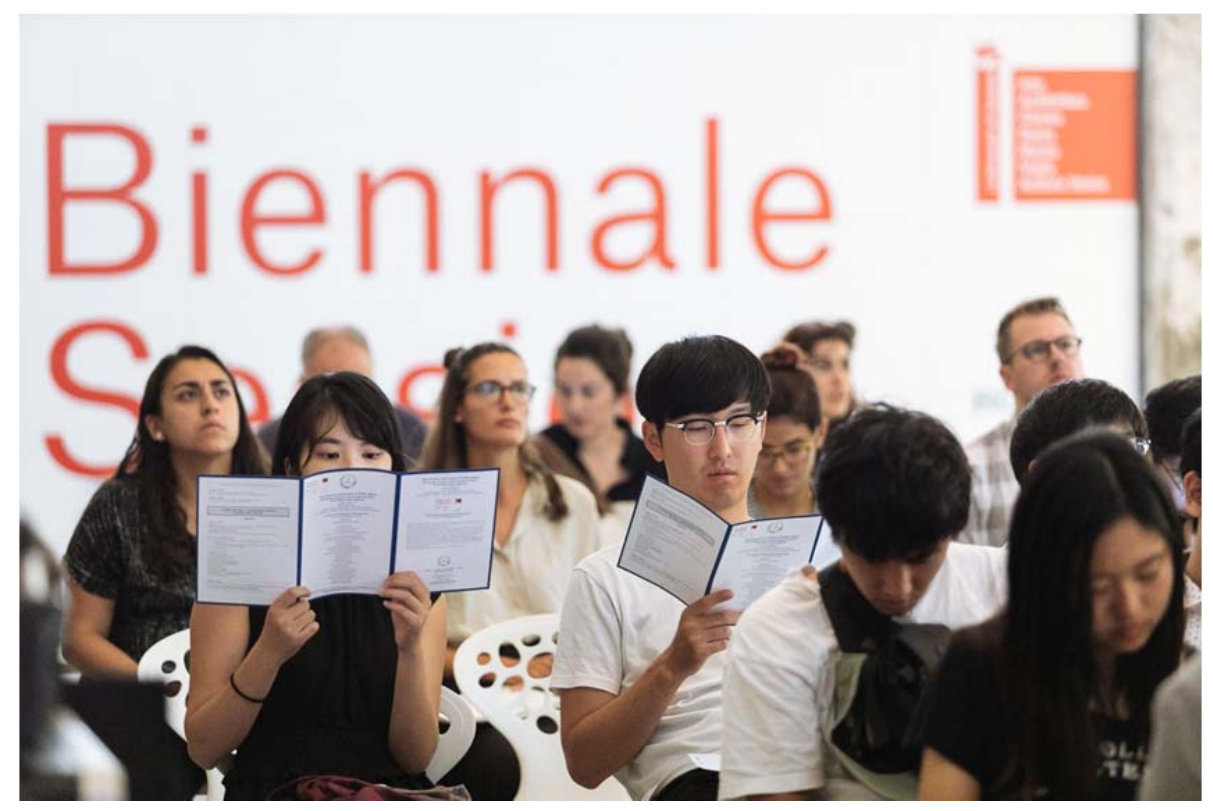

The conference in Venice was attended by 100 participants from all over the world, with more than 30 international academic speakers with about 50 international Master and $\mathrm{PhD}$ students. The outcomes of the event were shared by Pratt Institute ${ }^{8}$ and co+labo Radovic at Keio University ${ }^{9}$ on their website and also on social media by many participants.

This issue of The Journal of Public Space, Vol. 4, n. 4 (2019), hosts a section dedicated to the publication of several articles that were presented at the conference in Venice in 2018. As Scientific Coordinator of the 'Past Present and Future of Public Space' conference series, I'm glad to see the growing interest of academic institutions to invest in public space culture and I hope for a larger engagement at the fourth conference that will take place in September 2020 at the $17^{\text {th }}$ International Architecture Exhibition in Venice, on the theme 'Shaping Resilient Communites',

\section{To cite this article:}

Bravo, L. (2019). Academic Learning about Public Space. Knowledge Sharing toward Implementation of the New Urban Agenda, The Journal of Public Space, 4(4), I09-I I4, DOI 10.3289I/jps.v4i4.1244

This article has been peer accepted for publication in The Journal of Public Space. This work is licensed under a Creative Commons Attribution - Non Commercial 4.0
International License https://creativecommons.org/licenses/by-nc/4.0/

\footnotetext{
${ }^{8}$ Pratt Institute, news on the conference in Venice: https://www.pratt.edu/news/view/venice-architecturebiennale-2018-freespace-pratt-participates-in-symposium

${ }^{9}$ co+labo Radovic, Keio University, news on the conference in Venice:

http://colaboradovic.blogspot.com/2018_09_23_archive.html
} 